\title{
The Value of Sector Coupling for the Development of Offshore Power Grids
}

Gea-Bermúdez, Juan; Kitzing, Lena; Koivisto, Matti; Das, Kaushik; León, Juan Pablo Murcia; Sørensen, Poul

\section{Published in:}

Energies

Link to article, DOI:

10.3390/en15030747

Publication date:

2022

Document Version

Publisher's PDF, also known as Version of record

Link back to DTU Orbit

Citation (APA):

Gea-Bermúdez, J., Kitzing, L., Koivisto, M., Das, K., León, J. P. M., \& Sørensen, P. (2022). The Value of Sector Coupling for the Development of Offshore Power Grids. Energies, 15(3), [747]

https://doi.org/10.3390/en15030747

\section{General rights}

Copyright and moral rights for the publications made accessible in the public portal are retained by the authors and/or other copyright owners and it is a condition of accessing publications that users recognise and abide by the legal requirements associated with these rights.

- Users may download and print one copy of any publication from the public portal for the purpose of private study or research.

- You may not further distribute the material or use it for any profit-making activity or commercial gain

- You may freely distribute the URL identifying the publication in the public portal

If you believe that this document breaches copyright please contact us providing details, and we will remove access to the work immediately and investigate your claim 


\title{
Article \\ The Value of Sector Coupling for the Development of Offshore Power Grids
}

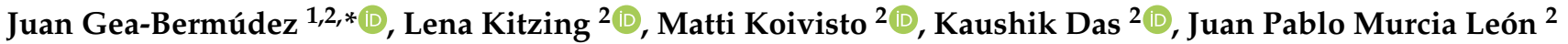 \\ and Poul Sørensen ${ }^{2}$ (i)
}

1 Department of Management, Technical University of Denmark (DTU), 2800 Lyngby, Denmark

2 Department of Wind Energy, Technical University of Denmark (DTU), 4000 Roskilde, Denmark; lkit@dtu.dk (L.K.); mkoi@dtu.dk (M.K.); kdas@dtu.dk (K.D.); jumu@dtu.dk (J.P.M.L.); posq@dtu.dk (P.S.)

* Correspondence: jgeab@dtu.dk

Citation: Gea-Bermúdez, J.; Kitzing, L.; Koivisto, M.; Das, K.; Murcia León, J.P.; Sørensen, P. The Value of Sector Coupling for the Development of Offshore Power Grids. Energies 2022, 15, 747. https://doi.org/10.3390/ en15030747

Academic Editors: José A.F.O.

Correia and Eugen Rusu

Received: 3 December 2021

Accepted: 11 January 2022

Published: 20 January 2022

Publisher's Note: MDPI stays neutral with regard to jurisdictional claims in published maps and institutional affiliations.

Copyright: (c) 2022 by the authors. Licensee MDPI, Basel, Switzerland. This article is an open access article distributed under the terms and conditions of the Creative Commons Attribution (CC BY) license (https:// creativecommons.org/licenses/by/ $4.0 /)$.

\begin{abstract}
Offshore grids can play key roles in the transition of energy systems toward sustainability. Although they require extensive infrastructure investments, they allow for the exploitation of additional resources and may be important in providing for part of the increasing electricity demands driven by sector coupling. This paper quantifies the socioeconomic value of offshore grids and identifies their major drivers, performing energy system optimization in a model application of the northern-central European energy system and the North Sea offshore grid towards 2050. The increasing wake loss with the sizes of hub-connected wind farms is integrated in the modeling. We find that without sector coupling no offshore grid may develop, and that the higher the level of sector coupling, the higher the value of offshore grids. Therefore, it can be strongly stated that offshore grid infrastructure development should not be discussed as a separate political topic, but seen in connection to sector coupling.
\end{abstract}

Keywords: sector coupling; offshore grid; optimization; sustainability transition; energy system modeling

\section{Introduction}

\subsection{Background}

Energy systems need to reduce emissions to sustainable levels [1]. Electricity, heat, and transport sectors all have their individual challenges in this transition. The existing literature shows that exploiting the synergies between the different parts of an energy system through sector coupling is key to achieve a cost-effective transition. Converting electricity to heat, liquid fuel, or gas will increase electricity consumption, and provide significant flexibility options for the electricity sector, which are required to integrate the increasing amounts of variable renewable energy (VRE) generation from solar photovoltaic (PV) and wind energy. Helgeson et al. [2] showed the benefit of co-optimizing and coupling the transport and electricity sectors. Gea-Bermúdez et al. [3] found that partial electrification of the industry sector reduces system costs. Both Thellufsen et al. [4] and Brown et al. [5] showed that both transmission expansion and sector coupling lead to lower system costs. By using the same model as Brown et al. [5], Victoria et al. [6] analyzed the role of different types of storage and found that electric vehicles may assist in the short-term balancing of the system, while large-scale thermal storage may assist in seasonal balancing. Gea-Bermúdez et al. [7] analyzed the role of sector coupling in the green transition, using a model, including the heat, transport, and electricity sectors, and found that the electrification of the heat sector is key to reduce emissions and costs in that sector. These papers show the value of sector coupling in decarbonized energy systems.

Offshore wind can be an important technology owing to higher capacity factors [8] and less challenges with social acceptance [9]. In line with this, the European Union has released its offshore renewable energy strategy [10]. To access additional offshore resource 
potentials, and to potentially reduce overall system cost [7], the idea of expanding the electricity system into the oceans and developing offshore grids is being discussed. In offshore grids, offshore wind farms are directly connected with each other (via hubs) to form meshed electrical networks instead of, as it is mostly done today, installing separate cables that bring the electricity of a single wind farm to an individual landing point onshore (referred to as radially connected in this paper). Developing offshore wind farms as part of integrated offshore grids can increase the value of offshore transmission lines, since the transmission lines that are part of the offshore grid can be used both to dispatch wind, and as interconnectors when the transmission lines are not congested due to offshore wind generation dispatch [7]. This double purpose can provide additional flexibility to the energy system with respect to radially connected offshore wind farms.

Previous studies have found that supplementing traditional offshore wind energy development with more advanced offshore grid configurations (Figure 1) reduces costs and fosters the integration of VRE, especially offshore wind, in the system [11]. The European Commission is already prioritizing the development of a North Sea offshore grid [12], for it to contribute to achieving the European Union goals for 2030 and 2050 [13]. Gea-Bermúdez et al. [7] investigated the influence of the grid architecture and planning horizon on the North Sea offshore grid, finding that offshore grids reduce system costs and that long-term planning is crucial to reduce costs and increase the integration of VRE, especially offshore wind. Konstantelos et al. [14] also found that integrated offshore grids provide substantial net benefit over non-integrated networks. Koivisto et al. [15] showed that both offshore grids and sector coupling individually lead to increased investments in offshore wind, although sector coupling has a larger influence on this matter: sector coupling increases investments in offshore wind by tens of gigawatts, whereas offshore grids by around $10 \mathrm{GW}$. However, the sector coupling scenario used did not include the possibility to build an advanced offshore grid, but only radially-connected offshore infrastructure.

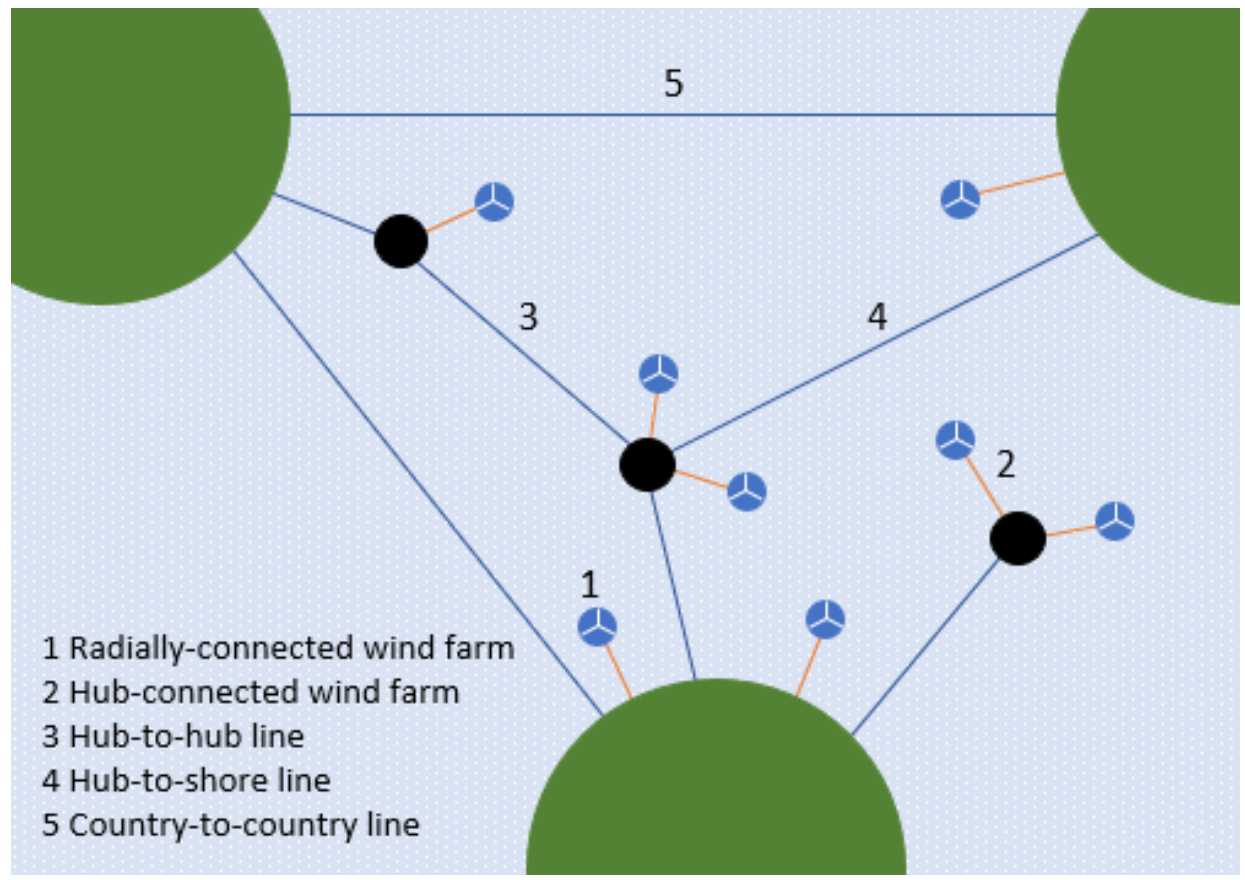

Figure 1. Possible configurations of offshore infrastructure.

Two effects need to be considered especially when modeling hub-connected offshore wind farms in offshore grids: energy losses due to wakes and spatial smoothing of wind farm generation due to the large wind farm size. These two factors can be important for radially-connected wind farms, but are considered in detail only for hub-connected wind farms because they are expected to be deployed in larger sizes, which magnifies 
the influence of these factors. Radially-connected wind farms are modeled with generic assumptions for these factors instead [7].

Wind farm wakes translate into energy losses due to the reduced energy available in the flow downstream of a single turbine or a wind farm. Energy wake losses are larger when the turbines are closely spaced and when there are more turbines, which can be especially relevant for hub-connected wind farms. This means that, given a constant installation density, the larger the installation capacity on a hub-connected wind farm the less efficient it will be. For example, reference [16] reports an increase in wake losses from $17 \%$ to $50 \%$ when increasing the installed capacity of a large wind farm from 0.14 to $210 \mathrm{GW}$ at a constant capacity density of $6.4 \mathrm{MW} / \mathrm{km}^{2}$ operating in the Danish North Sea; similar results are reported in [17].

Wake modeling is required to capture the decrease in efficiency for larger hubs in the wind generation time series required in all large energy system investment optimization studies [18]. Two methodologies can be used for wake modeling: using a parameterized representation of the wind farms in weather models $([16,17])$ or using engineering wake models to simulate individual wind turbines and farm wakes ([19-21]). Parameterized wakes inside weather models have the main advantage of capturing how the wake losses advect in the weather-driven wind fields, but require large simulations for each specific installation location. On the contrary, engineering wake models assume that the wind at a given time is spatially uniform over the whole farm. This means that wake modeling can be used to predict wake losses (or farm power curve) as a function of wind speed and direction independent of the actual location of the farm, and then use the time series of a wind-farm-free reanalysis or weather model to drive the farm power curve.

Spatial smoothing is the resulting decrease in the high frequency fluctuations in the aggregated hub-connected wind generation due to the distance between the individual turbines and farms. This smoothing effect is caused by the fact that correlation of the wind speed between two points decreases with their distance $([22,23])$; therefore, the fluctuations of generation in individual turbine or/and farm cancel each other when aggregating them into a large hub. Spatial smoothing is automatically captured when using wake parameterizations in weather models, while with engineering wake models, it is required to predict farm power curves for only smaller sub-components of a wind farm, and then do the aggregation after the power generation time series are extracted [19].

The offshore wind modeling of this paper uses engineering wake models because using parameterized representation when dealing with energy system capacity development optimization is challenging. Using a parameterized representation would imply a possibly never-ending iterative process, since to calculate wake losses using this approach one needs as input the installed capacity of the different wind units of the system, which is a result from the capacity development optimization.

\subsection{Contribution to the Literature}

The main contribution of this paper is to investigate the influence of sector coupling on the development of offshore grids. To our knowledge, the existing literature has not performed this task, and has focused on researching each of these aspects individually, ignoring potential synergies and influences between them. We find this analysis of great importance for the current discussion, since both offshore grids and sector coupling can be highly relevant in the future energy system.

Our analysis addresses this research gap by performing least-cost optimization of capacity development and operation of the energy system with varying levels of sector coupling of the European North Sea region towards 2050 from a socioeconomic perspective. The modeling integrates the potential increase of wake losses with the size of hub connected wind farm development in detail, which is an important novelty of this paper. To our knowledge, the existing literature has not included this aspect in the modeling of large-scale energy systems. 


\subsection{Structure of the Paper}

In Section 2, the model and data used are described. In Section 3, the scenarios are described. In Section 4, the results are shown and analyzed. In Section 5, the results are discussed, and conclusions are presented in Section 6.

\section{Methodology and Data}

This section provides an introduction to the models, data, and optimization approach used.

\subsection{Balmorel}

\subsubsection{General Description of the Model}

Balmorel [24] is a flexible structure, deterministic, bottom-up, energy-system model. In the recent years, Balmorel has been greatly developed by including more capabilities that allow for higher detail in the modeling of the operation of the system [25], and including more sectors [7]. The Balmorel energy system model and corresponding data are open source and can be accessed in [26,27] respectively.

Balmorel is used to perform cost-minimization of capacity development and operation towards 2050 while satisfying the energy demand of the following countries: the United Kingdom, France, Belgium, Netherlands, Germany, Poland, Finland, Norway, Sweden, and Denmark. The optimization is performed from a socioeconomic perspective and the time resolution is hourly. Existing bidding zones are used to define the spatial resolution used. Germany is divided into several region to capture intra-country bottlenecks. Demand for electricity, heat, and transport are included. Decarbonization towards 2050 of the transport sector is assumed. An overview of the possible synergies across the sectors modeled is presented in Figure 2.

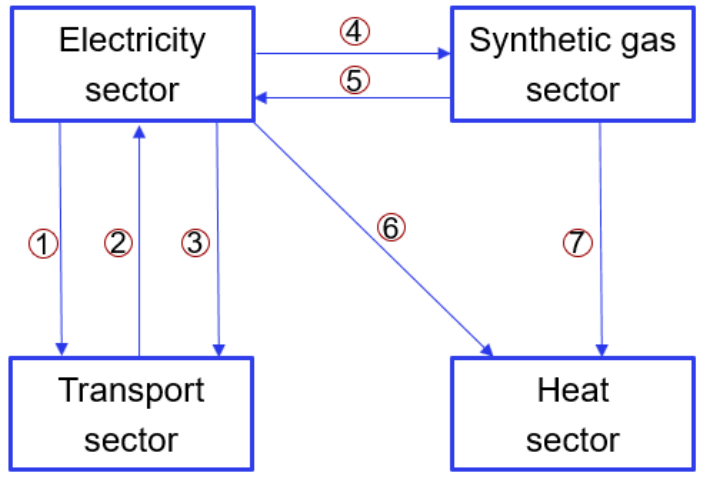

(1) Electricity grid to vehicle

(2) Vehicle to electricity grid

(3) Electricity to synthetic fuel generation

(4) Electricity to synthetic gas

(5) Synthetic gas to electricity

6) Electricity to heat and Combined heat and Power

(7) Synthetic gas to heat

Figure 2. Potential synergies across the modeled sectors. Figure taken from [7].

Minimizing discounted system costs is the objective function in the Balmorel model [24] (Equation (1)). The costs of each of the studied scenario years $(y)$ can be grouped in variable costs $\left(c_{y}^{\text {vom }}\right)$, fixed costs $\left(c_{y}^{f o m}\right)$, and annualized investment costs $\left(c_{y}^{i n v}\right)$. The investments costs are annualized using a socioeconomic interest rate of $4 \%$ [28]. Variable costs include operational costs, fuel costs, and $\mathrm{CO}_{2}$ tax. The following variables are optimized in Balmorel: investments (electricity transmission, district heating expansion, hydrogen $\left(\mathrm{H}_{2}\right)$ pipelines, generation units, storage units), and hourly operation of the technologies (generation, content of the storage, loading of the storage, trade of energy, and operation of electric vehicles (EV)). Particularly for hydro reservoirs without pumping, their content is modeled on a seasonal basis. Storage and generation units are allowed to mothball before they reach the last year of their lifetimes. Mothballing is another variable of Balmorel, which means that units are allowed to become inoperative during a particular year to avoid paying the fixed annual cost, and in future years become operative again. At the end of their lifetime, the units must decommission. Decommissioning costs for exogenous units are not part of the model. A discount rate of $4 \%$ based on [28] is used to discount the costs of future years. 
This discount rate is applied for calculating, for each modeled year, the discount factor $\left(D F_{y}\right)$. This factor represents the socioeconomic time value.

$$
\min _{c_{y}^{\text {fom }}, c_{y}^{\text {com }}, c_{y}^{\text {inv }}} \sum_{y}\left(c_{y}^{\text {fom }}+c_{y}^{v o m}+c_{y}^{i n v}\right) \cdot D F_{y}
$$

Other equations are operational constraints, storage, and commodity balance, and limits establishing resource potentials. Unit commitment constraints and costs are not included in the optimizations. The impact of this assumption should not be high since a large amount of flexibility options are included in Balmorel [29].

\subsubsection{Energy System Modeling in Balmorel}

Storage and Generation Units

Multiple storage and generation (dispatchable and non-dispatchable) units are included in the model, competing with each other. The data for most of the technologies are based on [28]. The investment cost development for selected technologies is presented in Table 1.

Table 1. Development of investment costs for selected large-scale key technologies in $\mathrm{M} €_{2016} / \mathrm{MW}$ (M€ $€_{2016} / \mathrm{MWh}$ for storage). Additional costs, such as variable fixed costs or operational fixed costs, are not shown, but can be accessed in [27]. The costs presented for electrolyzers and fuel cells are defined on the electric side.

\begin{tabular}{|c|c|c|c|c|}
\hline Technology & 2025 & 2035 & 2045 & Source \\
\hline $\begin{array}{c}\text { Offshore wind radial } \\
\text { (nearshore, AC, western Denmark) }\end{array}$ & 1.6609 & 1.5783 & 1.5140 & $\begin{array}{l}{[28,30]} \\
{[31,32]}\end{array}$ \\
\hline $\begin{array}{c}\text { Offshore wind radial } \\
\text { (far offshore, AC, western Denmark) }\end{array}$ & 2.0662 & 1.8781 & 1.7379 & $\begin{array}{l}{[28,30]} \\
{[31,32]}\end{array}$ \\
\hline $\begin{array}{c}\text { Offshore wind radial } \\
\text { (far offshore, DC, western Denmark) }\end{array}$ & 2.7208 & 2.4829 & 2.3139 & $\begin{array}{l}{[28,30]} \\
{[31,32]}\end{array}$ \\
\hline $\begin{array}{l}\text { Hub-connected offshore wind } \\
\quad(20 \mathrm{~m} \text { depth, step 1) }\end{array}$ & 2.0558 & 1.8420 & 1.7162 & $\begin{array}{l}{[28,30]} \\
{[31,32]}\end{array}$ \\
\hline $\begin{array}{l}\text { Hub-connected offshore wind } \\
\text { (20 m depth, step 2) }\end{array}$ & 2.0872 & 1.8734 & 1.7475 & $\begin{array}{l}{[28,30]} \\
{[31,32]}\end{array}$ \\
\hline $\begin{array}{l}\text { Hub-connected offshore wind } \\
\quad(20 \mathrm{~m} \text { depth, step } 3)\end{array}$ & 2.1182 & 1.9044 & 1.7786 & $\begin{array}{l}{[28,30]} \\
{[31,32]}\end{array}$ \\
\hline $\begin{array}{l}\text { Hub-connected offshore wind } \\
\text { (30 m depth, step 1) }\end{array}$ & 2.1658 & 1.9420 & 1.8062 & $\begin{array}{l}{[28,30]} \\
{[31,32]}\end{array}$ \\
\hline $\begin{array}{l}\text { Hub-connected offshore wind } \\
\text { (30 m depth, step 2) }\end{array}$ & 2.1972 & 1.9734 & 1.8375 & $\begin{array}{l}{[28,30]} \\
{[31,32]}\end{array}$ \\
\hline $\begin{array}{l}\text { Hub-connected offshore wind } \\
\text { (30 m depth, step } 3)\end{array}$ & 2.2282 & 2.0044 & 1.8686 & $\begin{array}{l}{[28,30]} \\
{[31,32]}\end{array}$ \\
\hline $\begin{array}{c}\text { Offshore hub } \\
\text { (platform and equipment) }\end{array}$ & 0.1860 & 0.1860 & 0.1683 & [30] \\
\hline Onshore wind & 1.2728 & 1.1456 & 1.0539 & [28] \\
\hline $\begin{array}{l}\text { Solar PV } \\
\text { (AC side) }\end{array}$ & 0.4200 & 0.3000 & 0.2600 & [28] \\
\hline $\begin{array}{c}\text { Gas turbine } \\
\text { (electricity only) }\end{array}$ & 0.5015 & 0.4760 & 0.4590 & [28] \\
\hline $\begin{array}{l}\text { Heat pump } \\
\text { (ground to water) }\end{array}$ & 0.6580 & 0.5922 & 0.5626 & [28] \\
\hline
\end{tabular}


Table 1. Cont.

\begin{tabular}{|c|c|c|c|c|}
\hline Technology & 2025 & 2035 & 2045 & Source \\
\hline Electrolyser (alkaline) & 0.6500 & 0.4500 & 0.3000 & [28] \\
\hline $\begin{array}{c}\text { Electrolyser (alkaline, } \\
\text { connected to district heating) }\end{array}$ & 0.6605 & 0.4605 & 0.3105 & [28] \\
\hline $\begin{array}{c}\text { Fuel cell } \\
\text { (solid oxide) }\end{array}$ & 1.5000 & 0.8000 & 0.6500 & [28] \\
\hline $\begin{array}{l}\text { Lithium battery } \\
\text { (electricity storage) }\end{array}$ & 0.4105 & 0.3284 & 0.2463 & [33] \\
\hline $\begin{array}{c}\text { Pumped hydro } \\
\text { (electricity storage) }\end{array}$ & 0.2908 & 0.2908 & 0.2908 & [28] \\
\hline $\begin{array}{c}\text { Steel tank } \\
\left(\mathrm{H}_{2} \text { storage }\right)\end{array}$ & 0.0570 & 0.0450 & 0.0270 & {$[28]$} \\
\hline $\begin{array}{c}\text { Water tank } \\
\text { (Heat storage) }\end{array}$ & 0.0030 & 0.0030 & 0.0030 & {$[28]$} \\
\hline $\begin{array}{c}\text { Pit } \\
\text { (heat storage, central) }\end{array}$ & 0.0015 & 0.0014 & 0.0013 & [28] \\
\hline $\begin{array}{c}\text { Pit } \\
\text { (heat storage, decentral) }\end{array}$ & 0.0005 & 0.0004 & 0.0004 & [28] \\
\hline
\end{tabular}

\section{Electricity Network}

The electricity flows across regions use net transfer capacities [34]. Transmission losses distinguish between direct current and alternating current. Distribution losses for storage and generation units are also accounted. The distance between the center of the polygons of the regions is used to calculate investment costs for new electricity transmission, with these costs based on $[35,36]$. New lines are assumed to have a 40 year lifetime. More details are in [7].

\section{Synthetic Gas}

The synthetic gas sector includes the energy balance of $\mathrm{H}_{2}$ and synthetic natural gas (SNG).

The SNG modeling is taken from [7]. The SNG balance is modeled as an international market on an hourly basis. SNG can be generated through methanation-direct air capture units, which consume heat, $\mathrm{H}_{2}$ and electricity. SNG can be used in gas units as a perfect replacement of fossil natural gas. The costs and constraints of natural gas networks, where SNG is assumed to be injected, are not included. This means that the generated SNG can be freely distributed around the modeled regions. SNG is assumed to be carbon neutral and, hence, their $\mathrm{CO}_{2}$ flows are ignored.

The modeling of $\mathrm{H}_{2}$ has as a starting point [7]. The $\mathrm{H}_{2}$ modeling includes: hourly energy balance and the possibility to transport $\mathrm{H}_{2}$ between regions via pipelines. Existing pipelines of $\mathrm{H}_{2}$ are not included. Investments in $\mathrm{H}_{2}$ transmission pipes are allowed and assumed to live for 50 years [28]. The investment costs of new pipes is $400 €_{2016} / \mathrm{km} / \mathrm{MW}_{\text {th }}$ and their transmission losses are $0.0022 \% / \mathrm{km}$ [28], which is the required energy to keep the operating pressure of the network (140 bar in this paper). Bi-directional linear flow is allowed in the pipes. Distribution $\mathrm{H}_{2}$ networks and their costs are not included, but their losses are. The conversion of existing natural gas networks into $\mathrm{H}_{2}$ network is not included. Technologies using $\mathrm{H}_{2}$ are not allowed to be installed in offshore hubs to reduce the complexity of the problem and because their costs and challenges are highly uncertain. Exogenous $\mathrm{H}_{2}$ demand to decarbonize the transport sector (explained later in this section) and the industrial sector is assumed. The $\mathrm{H}_{2}$ demand for industry is assumed constant along the year and is based on scenario 1.5TECH of the European Commission [37]. 


\section{Transport Sector}

Decarbonization towards 2050 of the transport sector is assumed and its modeling split into demand for synthetic fuels, and inflexible and flexible EVs.

Inflexible EVs includes rail transport and buses that are currently running on fossil fuels, which are assumed to fully electrify towards 2050 with data from [38]. They are modeled with exogenous demand time series in each region. For trains, the demand pattern is considered constant, whereas for buses, it is time dependent [39].

The rest of the road transport is modeled as flexible EVs. The modeling of EVs uses the concept of virtual storage in each region to consider the expected number of EVs that will be connected to the electricity network in each time step [40]. The total number of EVs in the different years is assumed and come from [39]. The model optimizes charging and discharging of EVs, and virtual storage content. EVs are split into plug-in hybrid EVs and battery EVs. Plug-in hybrid EVs are not allowed to be used to discharge electricity to the grid. The main equation of EVs is the hourly virtual storage balance. The level of the storage at the start of each modeled season (week) must be equal to the level in the end of the season. Minimum charging limits inflexible charging whereas maximum charging is limited by the charger capacity. The daily patterns assume that most EVs are not connected to the grid during most working hours (see Figure 3), based on the assumption that charging points will not be available in work places. The charging of EV incurs into distribution grid losses and charger losses. More details in [7].

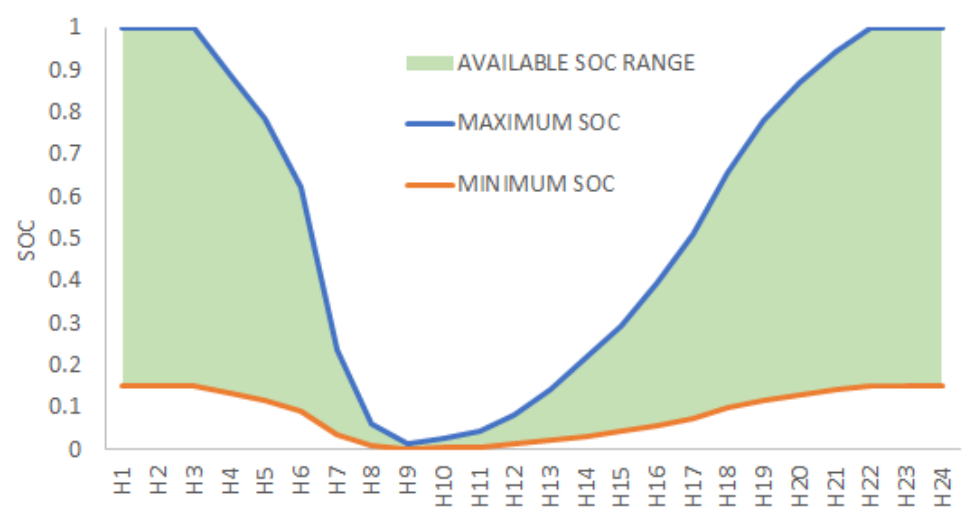

Figure 3. Illustration of the available state of charge (SOC) range of electric vehicles during the day.

The increasing synthetic fuel demand towards 2050 that would be required to decarbonize the aviation and shipping transport sectors of the countries included in the model is modeled as annual $\mathrm{H}_{2}$ demand based on [38] (Figure 4). The hourly distribution of this demand is optimized. The technologies consuming this $\mathrm{H}_{2}$ to generate synthetic fuels are not included to reduce the problem complexity. The operation of these units is indirectly restricted by establishing an upper limit to the peak-to-average ratio of the hourly $\mathrm{H}_{2}$ demand in each region. This limit is equivalent to establishing a minimum average capacity factor per region, which is assumed to be $2 / 3$ to consider that it is likely that these synthetic fuel plants will require high capacity factors to maximize their profits. The $\mathrm{H}_{2}$ demand for this sector has been obtained by assuming an efficiency of $62.5 \%$ to the electricity consumption numbers of [38]. The efficiency considers distribution losses, since $\mathrm{H}_{2}$ distribution networks are not modeled. When the $\mathrm{H}_{2}$ demand to generate synthetic fuels for the transport sector is included in the model, then investments in biomass units are not allowed, since it is likely that the generation of such synthetic fuels will require the use of almost all the available biomass resources [41]. This assumes that using the available biomass when combined with $\mathrm{H}_{2}$ to generate synthetic fuels provides higher value to the system than when using this biomass for other purposes, e.g., heat generation [41]. The challenges and costs regarding the transportation of biomass resources is not considered.

The operational and capital costs of the different means of transport (ships, cars, etc.) are not included. 
Heat Sector

The heat sector is divided into industry, district heating, and individual users (tertiary and residential sectors). District heating modeling, inspired in [42], considers different network scales. Investment costs for district heating expansion are assumed to be $400 \mathrm{M} €_{2016} / \mathrm{MW}_{\text {th }}$ [43], and their lifetime 40 years [28]. The modeling of individual users considers the end use of the heat demand of this sector: hot water or space heating. The heat demand modeling of the industry sector is modeled based on $[28,44,45]$, and considers three temperature levels: high temperature (above $500{ }^{\circ} \mathrm{C}$ ), medium temperature $\left(100-500{ }^{\circ} \mathrm{C}\right)$, and low temperature (below $\left.100^{\circ} \mathrm{C}\right)$. More details in [7].

\section{Energy Efficiency}

The European Commission's energy efficiency target by 2030 of a $32.5 \%$ decrease in final energy consumption is assumed to take place [13]. This assumption influences the exogenous electricity and heat demand development towards 2050 (Figure 4). The different demands related to the transport sector does not include this efficiency measure since the data used already include efficiency assumptions. Due to data availability, the year 2016 is used as the reference year instead of 2007, which is the one that the European Commission uses.

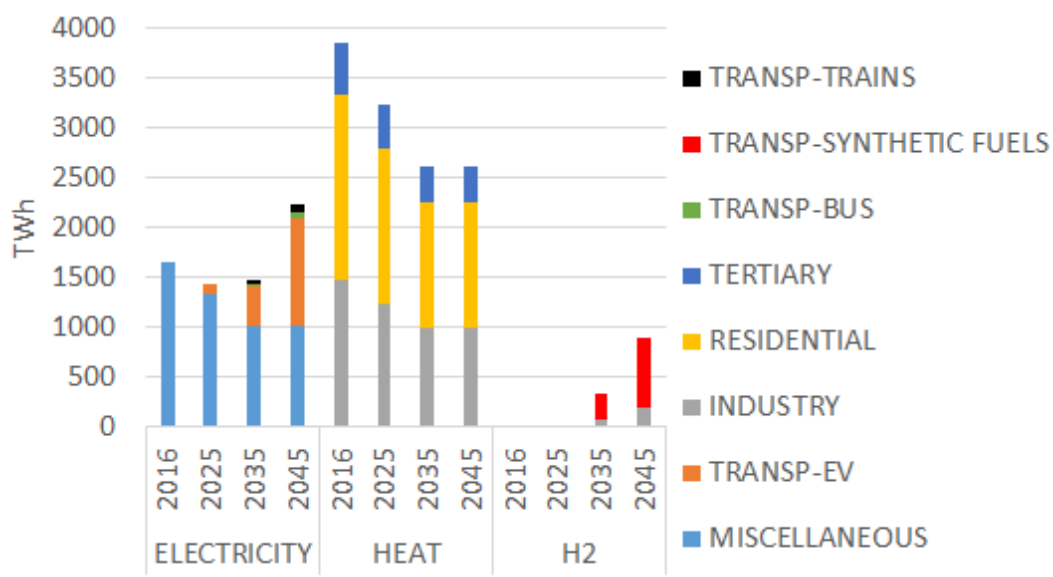

Figure 4. Exogenous demand scenario per year, sector, and commodity (TWh). Transport demand is only included in the scenarios with the transport sector. The year 2016 is the base year of the model and is not included in the optimizations.

\section{Wind and Solar Modeling}

The modeling of solar and wind technologies is based on resource grades inspired from [36], to represent that, inside the studied regions, wind and solar resources are not uniform. The resource grades can differ in time series, investable potential, and costs. In particular, radially-connected offshore wind farms are divided into three resource grades: far-offshore and near-shore connected with alternating-current, and far-offshore directcurrent connected. Hub-connected offshore wind farms are explained later. Offshore wind farm costs consider the influence of water depth using data from [31,32]. To simulate solar PV and wind time series, we use the CorRES model $([46,47])$. The weather year used for the time series corresponds to 2012; the same weather year is used for all demand time series.

National onshore wind potential is taken from [35], and accounts for 419 GW in the studied countries. This relatively low limit represents low social acceptability towards onshore wind. Large-scale solar PV potentials per country are taken from [48]. Radiallyconnected offshore wind farm potentials are based on [35,49]. More modeling details in [7]. 


\section{Fuel Price and $\mathrm{CO}_{2}$ Tax}

The development of fuel prices and $\mathrm{CO}_{2}$ tax towards 2050 is taken from [35]. The $\mathrm{CO}_{2}$ tax is used to trigger the decarbonization of the energy system. The $\mathrm{CO}_{2}$ tax levels for the years 2025, 2035, and 2045 correspond to $29.8,90.4,120.6 €_{2016} /$ ton, respectively. Other taxes are not included in the model.

Biofuel data are based on [50] and are assumed to be carbon neutral.

\subsubsection{Offshore Grid Modeling}

The offshore grid modeling is built upon the work presented in $[30,36]$. Offshore grids are modeled as individual regions, i.e., bidding zones, where offshore hub platforms, wind farms, and direct-current electrical interconnectors can be built. By modeling offshore grids as individual regions, possible congestion issues can be captured. Offshore grids are only allowed to be built in the North Sea (Figure 5). In this paper, offshore regions are interchangeably called hubs.

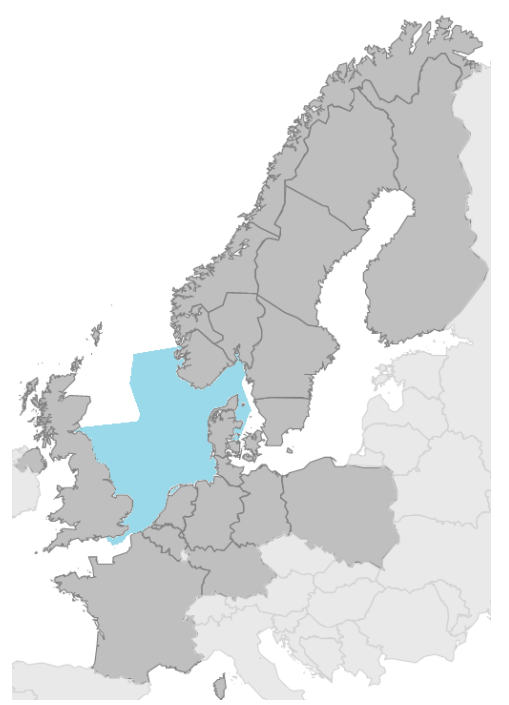

Figure 5. The regions included in the scenarios are colored in dark gray and the colored blue area shows what we consider to be part of the North Sea.

The size of the offshore hub platform installed in each offshore region is required to be as high as the maximum export of electricity taking place in that offshore region. Protection costs for the interconnectors are not included. The hubs can only be used to generate and trade electricity.

To model the relation between offshore wind farm size and wake losses in offshore grids, hub-connected wind farms are divided into three steps (Figure 6). We use three steps of hub-connected wind farms to reduce the complexity of the model, even though in reality wake losses increase non-linearly with the size of the wind farm. Each step is modeled with a different rated generation time series, and a maximum investable wind capacity potential: 2, 10, and $12 \mathrm{GW}$, for step 1, 2, and 3 respectively, leading to a maximum aggregated installable wind capacity of $24 \mathrm{GW}$ in each hub. These three steps aim to represent small ( $2 \mathrm{GW})$, medium $(10+2=12 \mathrm{GW})$ and large $(2+10+12=24 \mathrm{GW})$ hub sizes. The core idea in the modeling of wake losses is that, if the model invests fully in one or several steps, then the resulting time series of the aggregated wind farms should capture the wake losses of all the wind farms connected to the hub. A detailed explanation regarding the calculation of these time series is provided in Section 2.2. 


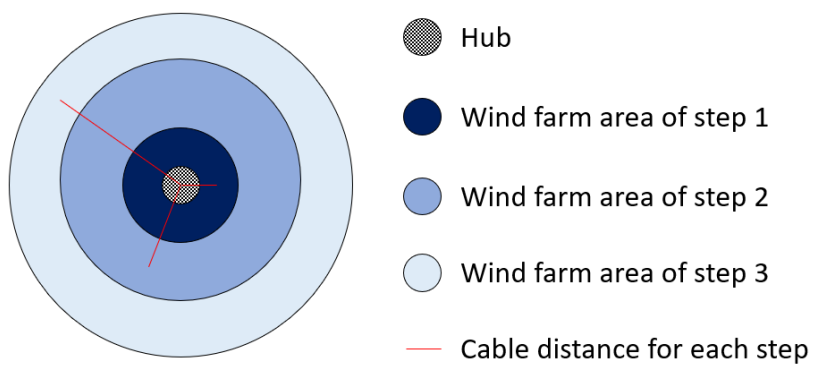

Figure 6. Illustration of hub-connected wind farm modeling, the area of the different wind farm steps, and the array cable distance used in the assumption calculation of each step.

The split into different steps is also used to model that the further away from the hub, the higher the transmission losses and costs are. The array cable distance considered for each step is assumed to be the middle point of each step area, i.e. the average between the longest radius and the shortest one in each step (Figure 6). The shortest distance in step 1 is assumed to be $0 \mathrm{~km}$ for simplicity. Assuming a capacity density of $7 \mathrm{MW} / \mathrm{km}^{2}$, circular layout of the wind farms, and the previously mentioned maximum investable capacity potential of each step, leads to cable distances of $4.8,16.5$, and $28.2 \mathrm{~km}$ for each step. The transmission losses of each step are assumed to be $1 \%, 1.25 \%$, and $1.5 \%$ for each step, respectively, based on [51].

\subsection{Large-Scale Hub-Connected Wind Farm Power Time Series Simulations \\ 2.2.1. Wake Modeling}

Circular energy hubs with installed wind farm capacities of 2, 12, and 24 GW are designed by ensuring an installation capacity density of $7 \mathrm{MW} / \mathrm{km}^{2}$. The different sizes correspond, respectively, to what the installed capacity of the aggregated hub-connected wind capacity in each hub would be if the first step was fully invested ( $2 \mathrm{GW})$, if the first and the second were fully invested $(2 \mathrm{GW}+10 \mathrm{GW}=12 \mathrm{GW})$, or if all steps were fully invested $(2 \mathrm{GW}+10 \mathrm{GW}+12 \mathrm{GW}=24 \mathrm{GW})$. All turbines are modeled using the expected turbine technology of [28] towards 2050, assuming a rated power of $18 \mathrm{MW}$ and a specific power of $340 \mathrm{~W} / \mathrm{m}^{2}$. Individual energy hub layouts have been generated by maximizing the spacing between turbines, see Figure 7 .
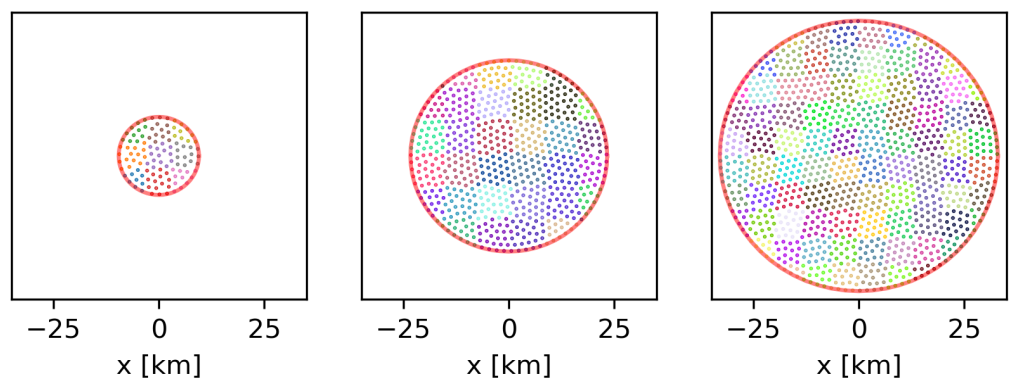

Figure 7. Hub layout (left) $2 \mathrm{GW}$ (center) $12 \mathrm{GW}$ (right) $24 \mathrm{GW}$. Each sub-farm is shown in different color.

Wake effects are modeled using the Gaussian wake model presented in [52]. This engineering wake model consists of self-similar Gaussian wind speed deficits, linear wake expansion and quadratic deficit superposition. The wake model is evaluated for all the turbines in the hub, but the resulting wake affected power curve is extracted per $8 \times 8 \mathrm{~km}$ sub-plans, see Figure 7. This provides an individual wake affected farm power curve (power as a function of wind speed and wind direction) per each sub-farm. 


\subsubsection{Large-Scale Hub-Connected Wind Generation Time Series}

The time series simulation consists of extracting the wind speed and wind direction time series at each sub-farm center from the meteorological weather data and then interpolate the farm power curve to derive rated power generation time series. The candidate locations for hub installations are depicted in Figure 8. The meteorological dataset is $10 \mathrm{~km} \times 10 \mathrm{~km}$ weather research and forecast model driven by ERA-interim boundary conditions, details on the weather modeling are given in [46]. Cubic-spline (horizontal) and piece-wise power law (vertical) interpolation is used to obtain 37 years on $1 \mathrm{~h}$ resolution wind speed time series on a given sub-farm center position.

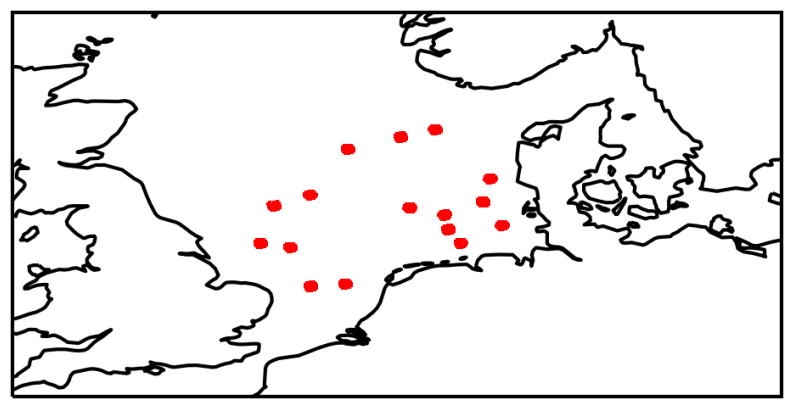

Figure 8. Candidate hub locations in the North Sea region.

An example of the resulting aggregated power curves for a location on the German waters is presented in Figure 9, which shows how the spatial smoothing changes the slope of the hub power curve, due to each sub-farm experiencing different wind speeds. In the left graphical presentation of Figure 9, power versus wind speeds are plotted and in the right graphical presentation, power versus cumulative density function is shown.
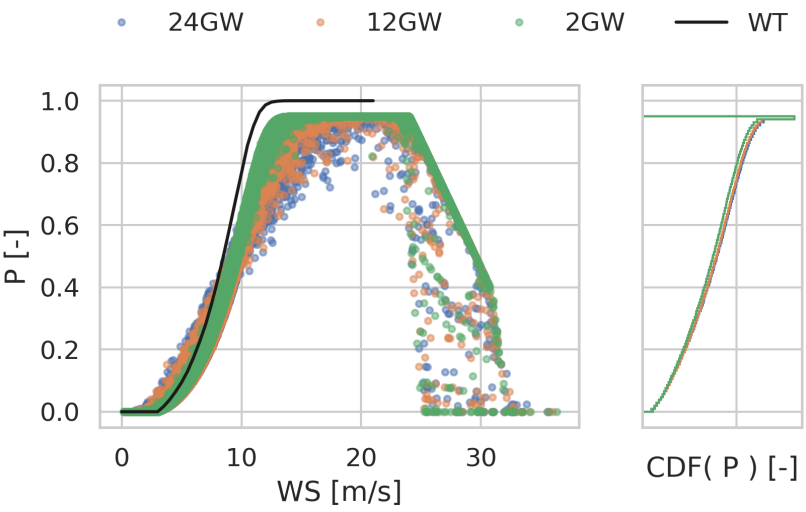

Figure 9. Example of resulting aggregated power curves for an example location on German waters. Power (P) versus wind speed (WS) (figure left) and power versus cumulative density function of power $(\mathrm{CDF}(\mathrm{P}))$ (right figure). WT stands for wind turbine.

The distribution of capacity factors across all locations is shown in Figure 10, which shows how the capacity factor decreases as a function of the installed capacity. Higher installed capacities lead to higher wake losses and, hence, to lower capacity factors of the locations. From Figure 10, it can be derived that the relation between wake losses and installed capacity is not linear. 


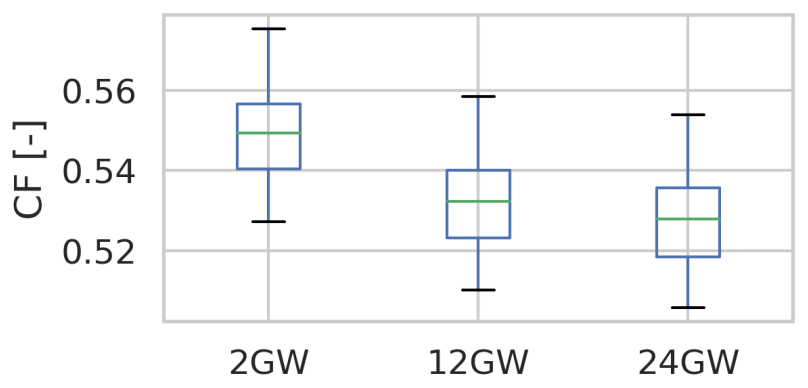

Figure 10. Distribution of capacity factors (CF) across all locations.

\subsubsection{Modification of Large-Scale Hub-Connected Wind Generation Time Series}

As mentioned previously, in Balmorel hub-connected wind farms are modeled with three steps. The steps differ in time series, wind farm cost assumptions, and investable wind farm capacity. Using directly the resulting rated power generation time series of the different wind farm sizes for each step, i.e., 2 GW for step 1, 12 GW for step 2, and 24 GW for step 3, would lead to an underestimation of the wake loss of the aggregated wind farm if the resulting installed capacity of the hub-connected wind farm is larger than $2 \mathrm{GW}$. This is because the wake losses that are part of the time series of step 1 only account for the wake losses corresponding to a wind farm size of $2 \mathrm{GW}$, ignoring additional wake losses incurred because of investing in step 2 and/or step 3. The same reasoning applies for the time series of step 2, which ignore additional wake losses incurred because of investing in step 3. For this reason, the original (non-modified) hourly time series of each hub-connected wind farm step is modified with Equation (2), to make sure that the resulting available hourly generation of the aggregated hub-connected wind farm in a particular offshore region captures the full wake loss of the full aggregated hub-connected wind farm. In Equation (2), for each offshore region, the modified rated generation $\left(P^{m o d}\right)$ of a particular hub-connected wind farm step $(k)$ in a time step $(t)$ is calculated using the original (non-modified) rated generation $\left(P^{o r i}\right)$, and the maximum investable capacity potential of each hub-connected wind farm step $\left(C^{\max }\right)$. The equation basically tends to scale down the rated generation time series of step 2 and 3 , resulting in lower average annual capacity factor of the modified time series (Table 2).

$$
\begin{gathered}
P_{t, k}^{\bmod }=\frac{1}{C_{k}^{\max }} \cdot\left(P_{k}^{\text {ori }} \cdot \sum_{1 \leq k^{\prime} \leq k} C_{k^{\prime}}^{\text {max }}-\sum_{k^{\prime}+1<k} P_{t, k^{\prime}}^{\bmod } \cdot C_{k^{\prime}}^{\max }\right) \\
\forall t, \forall k, k^{\prime} \in[1, k]
\end{gathered}
$$

Table 2. Average annual capacity factor of a wind farm installation far offshore in German waters for different installation sizes. Resulting values when not including wake loss modeling, when including wake loss modeling before modifying the time series with Equation (2), and when including wake loss modeling after modifying the time series with Equation (2).

\begin{tabular}{cccc}
\hline Time Series & $\mathbf{2 ~ G W}$ & $\mathbf{1 2} \mathbf{G W}$ & $\mathbf{2 4} \mathbf{G W}$ \\
\hline Without wake loss modeling & $59.7 \%$ & $59.7 \%$ & $59.7 \%$ \\
\hline $\begin{array}{c}\text { With wake loss modeling, } \\
\text { non-modified }\end{array}$ & $54.1 \%$ & $52.4 \%$ & $51.9 \%$ \\
\hline With wake loss modeling, modified & $54.1 \%$ & $52.0 \%$ & $51.5 \%$ \\
\hline
\end{tabular}

\subsection{Optimization Approach}

The capacity development and operation optimization of each scenario is performed with limited intertemporal foresight [36]. A two-year rolling horizon approach is used, which means that when planning 2025, the year 2035 is also known, and so on. 
To reduce the complexity of the problem, a reduced number of time steps are selected in the optimizations. These time steps are selected with the approach explained in [36]. The selected time steps of this paper correspond to 8 weeks distributed over the year, but using only Thursday, Friday, and Saturday, with one every three hours of these days. To keep annual statistical properties of the different time series, the values of the selected time steps are scaled with the approach used in [36], which is based on probability integral transformations. We use multiple years of weather data in the scaling to improve the representation of VRE in the selected time steps. This approach is used for all time series, except for EV time series, which correspond to the average of three consecutive hours, and the seasonal inflow of hydro, which is scaled in a linear way, with respect to their annual average inflow.

For each scenario, two optimizations are performed. The first optimization uses linear programming, and the second one uses mixed integer programming. The main purpose of the first optimization is to have all technologies compete with each other. The objective of the second optimization is to model economies of scale of offshore grids, using a similar approach as in [36], which leads to a reduced number of small investments. The investments, decommissioning, and/or mothballing of the first optimization are forced in the second optimization for almost all technologies for tractability purposes. The exceptions are offshore grid elements in the North Sea.

\section{Scenarios}

To analyze the influence of sector coupling between the different sectors in the offshore grid development, we run four scenarios with different levels of coupling between sectors: from status quo to high coupling of the electricity, heat, and transport sectors (Table 3). The different sector coupling options are added in stages to identify the impact of each sector on the development of offshore grids.

Table 3. Scenarios of this paper. "-" means not included, and "+" included.

\begin{tabular}{ccc}
\hline Scenario & $\begin{array}{c}\text { Investments in } \\
\text { Electric } \\
\text { Power-to-Heat Units }\end{array}$ & $\begin{array}{c}\text { Decarbonization } \\
\text { of the } \\
\text { Transport Sector }\end{array}$ \\
\hline Status quo & - & - \\
\hline Electricity and Heat & + & + \\
\hline $\begin{array}{c}\text { Electricity and Transport } \\
\text { Electricity, Heat and } \\
\text { Transport }\end{array}$ & - & + \\
\hline
\end{tabular}

\section{Results}

\subsection{Sector Coupling Drives Offshore Grids}

We find that the electrification of the energy sector with sector coupling leads to a substantial increase of the electricity demand towards 2050. The growth in electricity demand results in higher investments in solar PV, onshore wind, and offshore wind (hub-connected and radially-connected) (Figure 11) and, hence, substantially impacts the development of offshore grids. Compared to the scenario Status quo, the scenario where all the sectors are highly coupled (Electricity, Heat and Transport), will lead to, by 2045, 3.6 times higher electricity demand, and 4.8 times higher aggregated wind and solar generation. Part of the electricity demand that results from the integration of the sectors becomes considerably flexible due to the use of heat and $\mathrm{H}_{2}$ storage. In the scenario Electricity, Heat and Transport, by 2045 , heat storage will provide $14 \%$ of the total heat generation, and $\mathrm{H}_{2}$ storage $34 \%$ of the total $\mathrm{H}_{2}$ generation. Despite having 3.6 times higher electricity demand by 2045, the curtailment share, with respect to the total available electricity generation in that year, will be lower in scenario Electricity, Heat and Transport than in scenario Status quo: 3.6\% and $4.6 \%$, respectively. This highlights that sector coupling significantly contributes to the integration of VRE. 


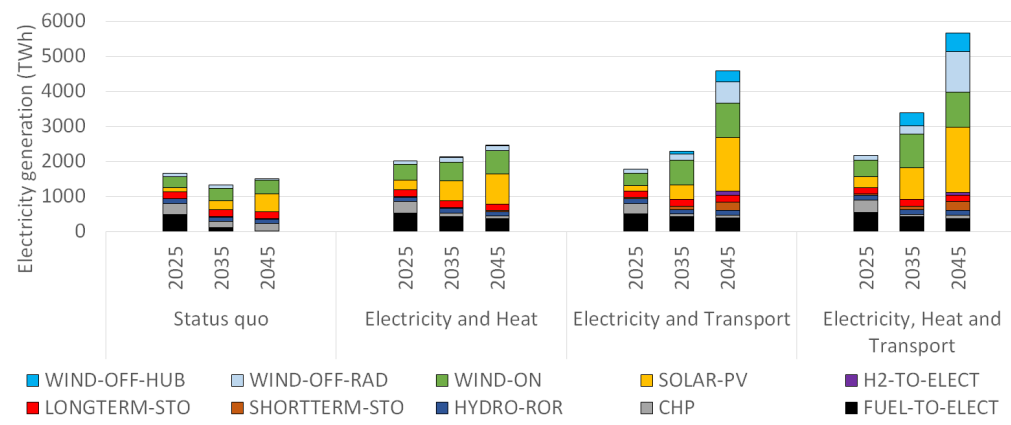

Figure 11. Electricity generation per scenario, year, and aggregated technology type in all the studied countries (TWh). Long-term electricity storage (LONGTERM-STO) includes large-scale hydro reservoirs without pumping. Short-term electricity storage (SHORTTERM-STO) includes hydro pumping and electric batteries (including electric vehicles).

The generation from offshore wind farms accounts for $43 \%$ of the additional electricity demand due to sector coupling, with $68 \%$ of the wind capacity being installed in the North Sea (Table 4). The results suggest that both radially-connected and hub-connected wind farms in the North Sea are likely to play a significant role, but that hub-connected wind farms are preferred. In the North Sea region, in the Electricity, Heat and Transport scenario, by 2045 , the installed capacity of hub-connected wind farms will account for $84 \%$ of the total offshore wind capacity. In the same scenario, by 2045, the installed capacity of offshore wind reaches $378 \mathrm{GW}$ ( $255 \mathrm{GW}$ in the North Sea).

Offshore grids will only be built from 2035 onward, and only when the heat and/or the transport sector are coupled with the electricity sector. The electrification of the heat sector on its own leads to much lower offshore grid development than the electrification of the transport sector on its own. This is highly influenced by the fact that resulting electricity demand towards 2045 will be much higher when the electricity and transport sector are coupled than when the electricity and heat sector are coupled.

In all scenarios, most of the hubs are designed with an aggregated interconnector capacity larger than the size of the wind farms connected to it (Figure 12). This result is likely to be influenced by the fact that the hubs are highly interconnected to each other (Figure 13) and, hence, the interconnectors of the hubs are designed considering the influence of the installed wind capacity in neighboring hubs, and not only the installed wind capacity in a particular hub. The fact that hubs are used to dispatch wind, and as interconnectors, combined with considering economies of scale, may also have influenced this result. In the Electricity, Heat and Transport scenario, by $2045,90 \%$ of the electricity export of hubs to the countries will be linked to hub-connected wind generation, and the remaining $10 \%$ to direct country-to-country dispatch.

The increasing need for flexibility towards 2050, due to the penetration of VRE in the system, is reflected with large investments in electrical interconnectors between the different regions of the model. The higher the electrical interconnector, the higher the maximum electricity trade that can take place between two different regions. In the Electricity, Heat and Transport scenario, the total TWkm of interconnectors will be 3.5 times the assumed-tobe existing interconnectors by 2025 (112 compared to 46 TWkm). The unit TWkm (TW times kilometers) is a convenient figure used to show the order of magnitude of the electricity grid, since it combines the electrical capacity (TW) and length of the cables (km). In the same scenario, $81 \%$ of the interconnectors in the North Sea are hub-connected, which means that these interconnectors are not always available for country-to-country dispatch (Table 4). Other sources of flexibility in the electricity sector, such as electric batteries or fuel cells, provide flexibility especially by 2045 , when the sectors are highly integrated. In the scenario Electricity, Heat and Transport, by 2045, fuel cells and short-term electricity storage will provide $1 \%$ and $4 \%$ of the total electricity generation, respectively, with $87 \%$ of the generation of electric batteries coming from flexible EVs. The use of SNG to replace part 
of the fossil natural gas generation will only take place by 2045 (114 TWh in the Electricity, Heat and Transport scenario).

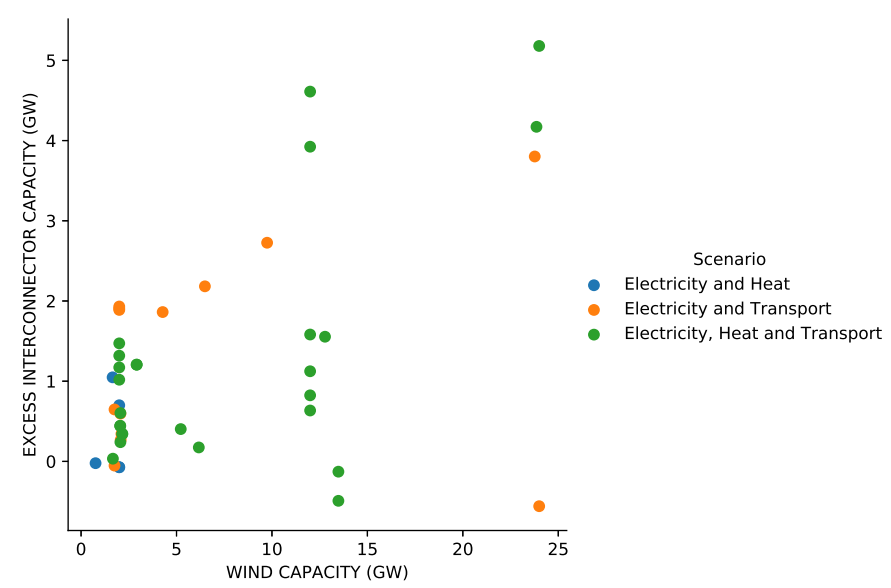

Figure 12. Excess interconnector capacity versus installed wind capacity in each hub in all studied years per scenario. Excess interconnector capacity is calculated as the difference between the aggregated electricity interconnector capacity of each hub and the installed wind capacity at the hub.

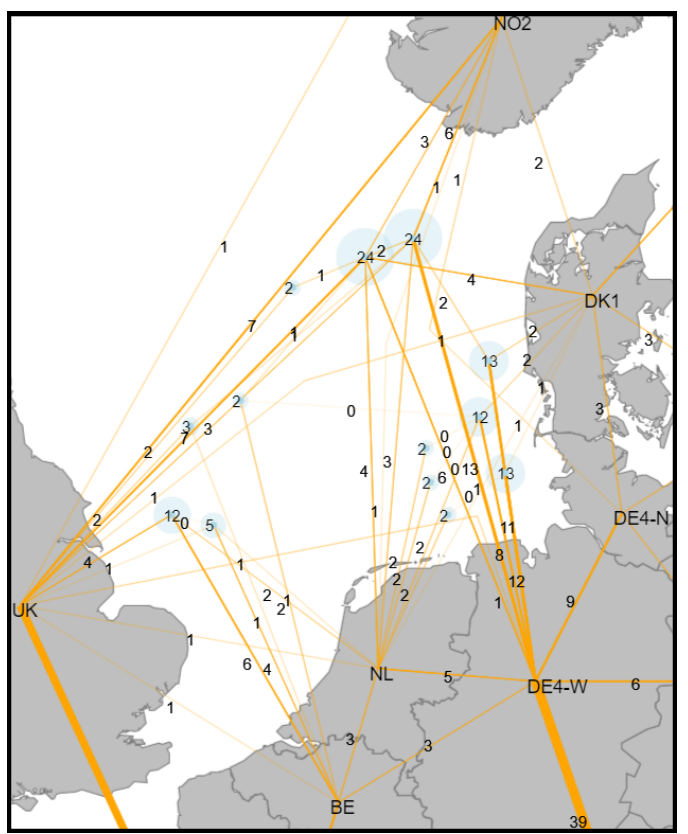

Figure 13. Transmission map of the North Sea region in 2045 in the scenario Electricity, Heat and Transport. The areas hub-connected wind farms would occupy are shown in the light blue circles, and the total sizes are shown in the middle of them. The small dark blue circle shows the locations of the invested hubs. Transmission lines (interconnectors) are colored in orange. All numbers are in GW and have been rounded.

\subsection{Sector Coupling Increases the Value of Offshore Grids}

Our results show that the value of offshore grids is highly influenced by the level of sector coupling and the importance of offshore wind in the system. Achievable system cost reductions are shown in Table 5. The highest analyzed sector coupling level can achieve an average annual saving of $1.25 \mathrm{~b} €_{2016}$ /year in the time period 2030-2050. When offshore grids are built, their higher capital expenditures are fully compensated by the reduction in investments and use of thermal power. In our scenarios, most of the savings take place in the period 2040-2050 (1.57 b€ $€_{2016}$ /year in the Electricity, Heat and Transport scenario), when the offshore grid starts to grow in size. 
Table 4. Summary of key results under different levels of sector coupling.

\begin{tabular}{|c|c|c|c|c|c|c|c|}
\hline \multirow[b]{2}{*}{ Sectors Coupled } & \multicolumn{3}{|c|}{ All Studied Countries in 2045} & \multicolumn{4}{|c|}{ North Sea Region in 2045} \\
\hline & $\begin{array}{l}\text { Electricity } \\
\text { Demand } \\
\text { (TWh) }\end{array}$ & $\begin{array}{c}\text { Installed Offshore } \\
\text { Wind Capacity } \\
\text { (GW) }\end{array}$ & $\begin{array}{l}\text { Share of Offshore } \\
\text { Wind in Electricity } \\
\text { Demand (\%) }\end{array}$ & $\begin{array}{c}\text { Installed Offshore } \\
\text { Wind Capacity } \\
\text { (GW) }\end{array}$ & $\begin{array}{c}\text { Hub-Connected } \\
\text { Capacity } \\
\text { Share }(\%)\end{array}$ & $\begin{array}{l}\text { Interconnectors } \\
\text { (TWkm) }\end{array}$ & $\begin{array}{c}\text { Share of } \\
\text { Hub-Connected } \\
\text { Interconnectors (\%) }\end{array}$ \\
\hline Status quo & 1491 & 12 & 3 & 8 & 0 & 6 & 0 \\
\hline Electricity and Heat & 2432 & 38 & 6 & 22 & 28 & 15 & 8 \\
\hline $\begin{array}{l}\text { Electricity and } \\
\text { Transport }\end{array}$ & 4331 & 203 & 21 & 148 & 86 & 38 & 72 \\
\hline $\begin{array}{c}\text { Electricity, Heat and } \\
\text { Transport }\end{array}$ & 5408 & 378 & 31 & 255 & 84 & 50 & 81 \\
\hline
\end{tabular}

Table 5. Influence of sector coupling on the value of offshore grids. Cost difference and relative change is calculated between the scenarios and a reference in which offshore grid investments are not allowed. Only scenarios with offshore grid investments are shown.

\begin{tabular}{|c|c|c|c|c|c|}
\hline Sectors Coupled & Time Period & $\begin{array}{c}\text { Difference in Capital } \\
\text { Expenditure }\left(b €_{2016} / \text { year }\right)\end{array}$ & $\begin{array}{l}\text { Difference in Operational } \\
\text { Expenditure (b€ } €_{2016} / \text { year) }\end{array}$ & $\begin{array}{c}\text { Total System Cost } \\
\text { Difference }\left(b €_{2016} / \text { year }\right)\end{array}$ & $\begin{array}{c}\text { Relative Change with Respect } \\
\text { to Total System Cost (\%) }\end{array}$ \\
\hline \multirow{3}{*}{ Electricity and Heat } & 2020-2030 & -0.02 & 0.02 & 0.00 & 0.00 \\
\hline & 2030-2040 & 0.18 & -0.17 & 0.00 & 0.00 \\
\hline & 2040-2050 & 0.15 & -0.16 & -0.01 & -0.01 \\
\hline \multirow[b]{2}{*}{ Electricity and Transport } & 2020-2030 & 0.04 & -0.03 & 0.01 & 0.01 \\
\hline & 2030-2040 & 0.38 & -0.36 & 0.02 & 0.01 \\
\hline \multirow{3}{*}{ Electricity, Heat and Transport } & $2020-2030$ & -0.07 & 0.07 & 0.00 & 0.00 \\
\hline & 2030-2040 & 1.35 & -2.28 & -0.93 & -0.63 \\
\hline & $2040-2050$ & -2.34 & 0.76 & -1.57 & -0.71 \\
\hline
\end{tabular}


Restricting the possibility of developing offshore grids leads to more installed capacity and utilization of thermal units, and additional emissions in the period from 2020 to 2050: 32, 54,000, and 59,000 ktons in scenarios Electricity and Heat, Electricity and Transport, Electricity, Heat and Transport, respectively. In scenarios Electricity and Transport, Electricity, Heat and Transport, investments in hub-connected wind farms (which are part of offshore grids) are much higher than in the Electricity and Heat scenario, leading to higher influence on emissions.

These results suggest that the system achieved is more integrated and efficient when offshore grids are developed. This is highly influenced by the fact that hub-connected lines are both used to dispatch offshore wind and as country-to-country interconnectors, which leads to a more efficient use of the grid infrastructure.

We observe that intertemporal optimization plays an significant role in the achievable cost reductions, i.e., anticipatory investments of hub infrastructure in early years contribute to cost reductions in later years. In scenario Electricity and Transport, the annual costs in the periods 2020-2030 and 2030-2040 will increase and lead to higher benefits by 2040-2050.

\section{Discussion}

The results of this paper are overall in line with European Commission scenarios towards 2050 [37]. For instance, the scenario with the highest degree of sector coupling, i.e., Electricity, Heat and Transport, will lead to a total installed capacity of offshore wind of 378 GW in the studied countries by 2045 . This result is in line with the $367 \mathrm{GW}$ of offshore wind capacity in the same countries by 2050, suggested in [53], which is based on the 450 GW European Commission's 1.5TECH scenario [37] for Europe, obtained using the PRIMES model [54]. However, the share of solar PV generation in the electricity generation mix differs considerably: by 2050, it will be 15-16\% in the European Commission scenarios, whereas in scenario Electricity, Heat and Transport, it will be 33\% by 2045 . As suggested in [55], the solar PV modeling assumptions may have been too conservative in the European Commission scenarios, which can be explained by the use of annual resolution and too high solar PV integration costs. Using hourly resolution, as it was done in this paper, is likely to be a better approach to capture the integration costs of solar PV.

In this paper, offshore grids are found beneficial for the future energy system. The savings that offshore grids can offer to the system are quantified as $1.25 \mathrm{~b} €_{2016}$ /year in scenario Electricity, Heat and Transport, in the period 2030-2050. These savings are higher than the $0.5 \mathrm{~b} €_{2016}$ /year in the same period that was found in [36]. The lower degree of sector coupling and corresponding electrification in [36] is behind this difference. Furthermore, offshore grids lead to less $\mathrm{CO}_{2}$ emissions towards 2050, reducing by 59,000 ktons the accumulated emissions between 2020 and 2050 in the scenario with the highest level of sector coupling (Electricity, Heat and Transport).

Apart from the quantitative added value that offshore grids provide to the system, there is further value potential that we discuss here qualitatively. Developing offshore grids could bring additional value to the energy system in areas such as grid reliability, adequacy, or system balancing. Increasing the number of potential interconnectors between countries can increase the flexibility of the system when balancing actions are required, leading to higher adequacy of the system and reliability of the grid. These additional sources of value for offshore grids should be investigated in future work. Carefully designing the electrical protection of offshore grids might be important to benefit from this additional value, since the costs associated to the protection of the offshore grid are not necessarily negligible [56] and can influence the economic value of offshore grids [30].

The results show that, although important, sector coupling itself is not a sufficient condition for the development of offshore grids, and that there are several factors that, when combined, lead to strong offshore grid development.

A determinant factor is the role of offshore wind in the system. The main factors behind the limited role of offshore wind are the assumptions on VRE technology, and the 
characteristics and energy levels of the electricity demand coming from the integration of the different sectors.

Onshore and offshore wind generation time series in the same region are relatively strongly correlated, as it is frequently the case, as shown in [57]. This suggests that the one with a more competitive combination of costs and energy yield is likely to be preferred. Although capacity factors are high in offshore, especially far from shore, with the cost projections from [28], onshore wind is generally preferred over offshore in the energy system optimization. This is in line with [58], which shows that onshore wind is one of the cheapest sources of electricity. Therefore, unless most of the good locations for onshore wind are used, offshore wind is not likely to play a significant role in the energy system. Alternative VRE technology assumptions, such as the ones presented in [59], which foresee a faster decrease of offshore wind cost development compared to [28], would have increased investments in offshore wind, and, probably, already in early years. In reality, onshore wind is experiencing public acceptance issues $([60,61])$, which is one of the reasons why companies and countries are putting the focus on offshore development [62]. Including in the modeling behavioral aspects instead of just relying on economic rationality should be considered in future work.

The electricity demand associated to the generation of heat or $\mathrm{H}_{2}$ can become quite flexible thanks to the use of heat or $\mathrm{H}_{2}$ storage, respectively, which favor solar PV generation. The availability patterns of EVs assumed favor a more stable source of electricity generation, like wind, which favors offshore grid development. This is reflected in the results of Figure 11, which show that even with similar level of generation by 2035, wind energy plays a larger role in scenario Electricity and Transport than in Electricity and Heat. When all sectors are highly coupled (scenario Electricity, Heat and Transport), then the electricity demand reaches a level that requires significant offshore wind generation. This occurs because the best locations for onshore wind have been exhausted.

This paper used a unique weather year in the analysis. Future research should consider the uncertainty of VRE generation, especially offshore wind, when planning future offshore grids, since they can potentially influence the optimal development of these networks.

Our results call for strong international cooperation, since the benefits of offshore grids are not likely to be equally distributed among the different countries, as shown in [14].

\section{Conclusions}

This work has shown that sector coupling is decisive for the future development of offshore grids. Because of considerably increasing overall electricity demands due to electrification in different energy sectors, more offshore wind development is expected to be required. Much of this may optimally be built in hubs and interconnected offshore grids. The larger the level of the sector coupling in the system, the higher the socioeconomic value that the offshore grids can offer to the energy system. Our results also show that the electrification of the transport sector favors offshore grid development more than the electrification of the heat sector.

We arrived at these findings by performing energy system optimization towards 2050 in green transition scenarios for Europe. We used the North Sea region's offshore area as a study case, but expect that the conclusions are applicable to other coastal nations around the world with decarbonization options through offshore wind development. Therefore, offshore grid infrastructure development cannot be discussed as a separate political topicit has to be seen in connection with sector coupling, as it is the integration between the different sectors of the energy system where offshore grids derive most of their value from.

Author Contributions: Conceptualization, J.G.-B., L.K., M.K., K.D., J.P.M.L., P.S.; methodology, J.G.-B., M.K., J.P.M.L.; software, J.G.-B.; resources, J.G.-B., M.K., J.P.M.L.; writing-original draft preparation, J.G.-B., J.P.M.L.; writing-review and editing, J.G.-B., L.K., M.K., K.D., J.P.M.L., P.S.; visualization, J.G.-B., J.P.M.L. All authors have read and agreed to the published version of the manuscript. 
Funding: This article is a part of NSON-DK and Flex4RES projects funded by the Danish Energy Agency, EUDP (grant 64018-0032; previously ForskEL) and Nordic Energy Research (grant 76084), respectively. Support from the ForskEL/EUDP OffshoreWake project (PSO-12521), Nordic Energy Research BaltHub project (106840), and La Cour Fellowship/DTU Wind Energy PSfuture project are also acknowledged.

Institutional Review Board Statement: Not applicable.

Informed Consent Statement: Not applicable.

Data Availability Statement: The Balmorel energy system model and corresponding data used for this paper can be accessed in [26,27], respectively. In this paper, the branch used for the code and data is "H2_Transport_update_2021_JGB" (last access 1 May 2021).

Conflicts of Interest: The authors declare no conflict of interest.

\section{Abbreviations}

The following abbreviations are used in this manuscript:

$\begin{array}{ll}\text { VRE } & \text { variable renewable energy } \\ \text { PV } & \text { photovoltaic } \\ \mathrm{H}_{2} & \text { hydrogen } \\ \text { EV } & \text { electric vehicle } \\ \text { SNG } & \text { synthetic natural gas }\end{array}$

\section{References}

1. UNFCC. Adoption of the Paris Agreement; UNFCC: Bonn, Germany, 2015.

2. Helgeson, B.; Peter, J. The role of electricity in decarbonizing European road transport-Development and assessment of an integrated multi-sectoral model. Appl. Energy 2020, 262, 114365. [CrossRef]

3. Gea-Bermúdez, J.; Koivisto, M.; Münster, M. Optimization of the electricity and heating sectors development in the North Sea region towards 2050. In Proceedings of the 18th Wind Integration Workshop, Dublin, Ireland, 16-18 October 2019.

4. Thellufsen, J.Z.; Lund, H. Cross-border versus cross-sector interconnectivity in renewable energy systems. Energy 2017, 124, 492-501. [CrossRef]

5. Brown, T.; Schlachtberger, D.; Kies, A.; Schramm, S.; Greiner, M. Synergies of sector coupling and transmission reinforcement in a cost-optimised, highly renewable European energy system. Energy 2018, 160, 720-739. [CrossRef]

6. Victoria, M.; Zhu, K.; Brown, T.; Andresen, G.B.; Greiner, M. The role of storage technologies throughout the decarbonisation of the sector-coupled European energy system. Energy Convers. Manag. 2019, 201, 111977. [CrossRef]

7. Gea-Bermúdez, J.; Jensen, I.G.; Münster, M.; Koivisto, M.; Kirkerud, J.G.; Chen, Y.K.; Ravn, H. The role of sector coupling in the green transition: A least-cost energy system development in Northern-central Europe towards 2050. Appl. Energy 2021, 289, 116685. [CrossRef]

8. The Global Wind Atlas. Global Wind Atlas; The Global Wind Atlas. 2021. Available online: https://globalwindatlas.info/ (accessed on 2 December 2021).

9. Egelund, O.B. Wind Energy and Local Acceptance: How to Get Beyond the Nimby Effect. Eur. Energy Environ. Law Rev. 2010, 19, 239-251.

10. The European Commission. EU Strategy on Offshore Renewable Energy; The European Commission: Brussels, Belgium, 2020.

11. European Comission. Offshore Electricity Grid Infrastructure in Europe; European Comission: Brussels, Belgium, 2011.

12. European Comission. Energy Infrastructure Priorities for 2020 and Beyond-A Blueprint for an Integrated European Energy Network; European Comission: Brussels, Belgium, 2011.

13. The European Commission. Climate Strategies and Targets; The European Commission: Brussels, Belgium, 2020.

14. Konstantelos, I.; Pudjianto, D.; Strbac, G.; De Decker, J.; Joseph, P.; Flament, A.; Kreutzkamp, P.; Genoese, F.; Rehfeldt, L.; Wallasch, A.K.; et al. Integrated North Sea grids: The costs, the benefits and their distribution between countries. Energy Policy 2017, 101, 28-41. [CrossRef]

15. Koivisto, M.; Gea-Bermúdez, J.; Kanellas, P.; Das, K.; Sørensen, P. North Sea region energy system towards 2050: Integrated offshore grid and sector coupling drive offshore wind power installations. Wind Energy Sci. 2020, 5, 1705-1712. [CrossRef]

16. Volker, P.J.H.; Hahmann, A.N.; Badger, J.; Jørgensen, H.E. Prospects for generating electricity by large onshore and offshore wind farms. Environ. Res. Lett. 2017, 12, 034022. [CrossRef]

17. Agora Energiewende; Agora Verkehrswende; Technical University of Denmark; Max-Planck-Institute for Biogeochemistry. Making the Most of Offshore Wind: Re-Evaluating the Potential of Offshore Wind in the German North Sea; Technical Report; Agora Energiewende: Berlin, Germany, 2020. 
18. Holttinen, H.; Meibom, P.; Orths, A.; Lange, B.; O’Malley, M.; Tande, J.O.; Estanqueiro, A.; Gomez, E.; Söder, L.; Strbac, G.; et al. Impacts of large amounts of wind power on design and operation of power systems, results of IEA collaboration. Wind Energy 2011, 14, 179-192. [CrossRef]

19. Murcia Leon, J.P.; Koivisto, M.J.; Sørensen, P.; Magnant, P. Power fluctuations in high-installation-density offshore wind fleets. Wind Energy Sci. 2021, 6, 461-476. [CrossRef]

20. Van der Laan, M.; Hansen, K.S.; Sørensen, N.N.; Réthoré, P.E. Predicting wind farm wake interaction with RANS: An investigation of the Coriolis force. In Journal of Physics: Conference Series; IOP Publishing: Bristol, UK, 2015; Volume 625, p. 012026. [CrossRef]

21. Nygaard, N.G.; Hansen, S.D. Wake effects between two neighbouring wind farms. In Journal of Physics: Conference Series; IOP Publishing: Bristol, UK, 2016; Volume 753, p. 032020. [CrossRef]

22. Santos-Alamillos, F.; Thomaidis, N.; Usaola-García, J.; Ruiz-Arias, J.; Pozo-Vázquez, D. Exploring the mean-variance portfolio optimization approach for planning wind repowering actions in Spain. Renew. Energy 2017, 106, 335-342. [CrossRef]

23. Koivisto, M.; Ekström, J.; Seppänen, J.; Mellin, I.; Millar, J.; Haarla, L. A statistical model for comparing future wind power scenarios with varying geographical distribution of installed generation capacity. Wind Energy 2016, 19, 665-679. [CrossRef]

24. Wiese, F.; Bramstoft, R.; Koduvere, H.; Alonso, A.P.; Balyk, O.; Kirkerud, J.G.; Tveten, Å.G.; Bolkesjø, T.F.; Münster, M.; Ravn, H. Balmorel open source energy system model. Energy Strategy Rev. 2018, 20, 26-34. [CrossRef]

25. Gea-Bermúdez, J.; Das, K.; Koivisto, M.J.; Koduvere, H. Day-ahead Market Modelling of Large-scale Highly-renewable Multienergy Systems: Analysis of the North Sea Region towards 2050. Energies 2021, 14, 88. [CrossRef]

26. Balmorel Community. Balmorel Code. Available online: https://github.com/balmorelcommunity/Balmorel (accessed on 2 December 2021).

27. Balmorel Community. Balmorel Data. Available online: https://github.com/balmorelcommunity/Balmorel_data (accessed on 2 December 2021).

28. Danish Energy Agency. Technology Catalogues; Danish Energy Agency: København, Denmark, 2020.

29. Poncelet, K.; Delarue, E.; D'haeseleer, W. Unit commitment constraints in long-term planning models: Relevance, pitfalls and the role of assumptions on flexibility. Appl. Energy 2020, 258, 113843. [CrossRef]

30. Koivisto, M.; Gea-Bermúdez, J.; Sørensen, P. North Sea offshore grid development: Combined optimization of grid and generation investments towards 2050. IET Renew. Power Gener. 2019, 14, 1259-1267. [CrossRef]

31. EA Energy Analysis. Offshore Wind and Infrastructure; EA Energy Analysis: København, Denmark, 2020.

32. EDMOnet-Bathymetry. EMODnet DTM; EDMOnet-Bathymetry: Europe 2021. Available online: https://www.emodnet-bathymetry. eu/ (accessed on 2 December 2021).

33. Lazard's Levelized Cost of Storage Analysis 3.0. Available online: https://www.lazard.com/media/450338/lazard-levelizedcost-of-storage-version-30.pdf (accessed on 2 December 2021).

34. Gunkel, P.A.; Koduvere, H.; Kirkerud, J.G.; Fausto, F.J.; Ravn, H. Modelling transmission systems in energy system analysis: A comparative study. J. Environ. Manag. 2020, 262, 110289. [CrossRef]

35. Nordic Energy Research; International Energy Agency. Nordic Energy Technology Perspectives 2016 Report; Nordic Energy Research: Oslo, Norway; International Energy Agency: Paris, France, 2016.

36. Gea-Bermúdez, J.; Pade, L.L.; Koivisto, M.J.; Ravn, H. Optimal generation and transmission development of the North Sea region: Impact of grid architecture and planning horizon. Energy 2020, 191, 116512. [CrossRef]

37. European Commission. A Clean Planet for All a European Long-Term Strategic Vision for a Prosperous, Modern, Competitive and Climate Neutral Economy; European Commission: Brussels, Belgium, 2018.

38. Transport and Environment. How to Decarbonize the Transport Sector by 2050. Available online: https://www.transportenvironment. org/discover/how-decarbonise-european-transport-2050/ (accessed on 2 December 2021).

39. Swisher, P.. Modelling of Political and Technological Innovation on Northern Europe's Energy System towards 2050. Master's Thesis, Technical University of Denmark, Lyngby, Denmark, 2020.

40. Gunkel, P.A.; Bergaentzlé, C.; Græsted Jensen, I.; Scheller, F. From passive to active: Flexibility from electric vehicles in the context of transmission system development. Appl. Energy 2020, 277, 115526. [CrossRef]

41. Sims, R.E.; Mabee, W.; Saddler, J.N.; Taylor, M. An overview of second generation biofuel technologies. Bioresour. Technol. 2010, 101, 1570-1580. [CrossRef]

42. Münster, M.; Morthorst, P.E.; Larsen, H.V.; Bregnbæk, L.; Werling, J.; Lindboe, H.H.; Ravn, H. The role of district heating in the future Danish energy system. Energy 2012, 48, 47-55. [CrossRef]

43. Henning, H.M.; Palzer, A. A comprehensive model for the German electricity and heat sector in a future energy system with a dominant contribution from renewable energy technologies_Part I: Methodology. Renew. Sustain. Energy Rev. 2014, 30, 1003-1018. [CrossRef]

44. Rehfeldt, M.; Fleiter, T.; Toro, F. A bottom-up estimation of the heating and cooling demand in European industry. Energy Effic. 2018, 11, 1057-1082. [CrossRef]

45. Wiese, F.; Baldini, M. Conceptual model of the industry sector in an energy system model: A case study for Denmark. J. Clean. Prod. 2018, 203, 427-443. [CrossRef]

46. Nuño, E.; Maule, P.; Hahmann, A.; Cutululis, N.; Sørensen, P.; Karagali, I. Simulation of transcontinental wind and solar PV generation time series. Renew. Energy 2018, 118, 425-436. [CrossRef] 
47. Koivisto, M.; Das, K.; Guo, F.; Sørensen, P.; Nuño, E.; Cutululis, N.; Maule, P. Using time series simulation tools for assessing the effects of variable renewable energy generation on power and energy systems. Wiley Interdiscip. Rev. Energy Environ. 2019, 8, e329. [CrossRef]

48. Ruiz, P.; Nijs, W.; Tarvydas, D.; Sgobbi, A.; Zucker, A.; Pilli, R.; Jonsson, R.; Camia, A.; Thiel, C.; Hoyer-Klick, C.; et al. ENSPRESO-An open, EU-28 wide, transparent and coherent database of wind, solar and biomass energy potentials. Energy Strategy Rev. 2019, 26, 100379. [CrossRef]

49. Koivisto, M.; Gea-Bermúdez, J. NSON-DK Energy System Scenarios, 2nd ed.; DTU Wind Energy: Roskilde, Denmark, 2018. Available online: https:// orbit.dtu.dk/en/publications/nsondk-energy-system-scenarios--edition-2(a12307fd-b045-4d90-a7 45-38bca211b861).html (accessed on 2 December 2021).

50. Flex4RES Project. Flexible Nordic Energy Systems Summary Report; Nordic Energy Research: Oslo, Norway, 2019. Available online: https:/ / www.nordicenergy.org/wp-content/uploads/2019/07 / Flex4RES_final_summary_report_aug2019.pdf (accessed on 2 December 2021).

51. Negra, N.B.; Todorovic, J.; Ackermann, T. Loss evaluation of HVAC and HVDC transmission solutions for large offshore wind farms. Electr. Power Syst. Res. 2006, 76, 916-927. [CrossRef]

52. Bastankhah, M.; Porté-Agel, F. A new analytical model for wind-turbine wakes. Renew. Energy 2014, 70, 116-123. [CrossRef]

53. Wind Europe. Our Energy, Our Future. How Offshore Wind Will Help Europe Go Carbon-Neutral; Wind Europe: Brussels, Belgium, 2019.

54. E3MLAB. PRIMES Model; E3MLAB: Athens, Greece, 2018.

55. Victoria, M.; Haegel, N.; Peters, I.M.; Sinton, R.; Jäger-Waldau, A.; del Cañizo, C.; Breyer, C.; Stocks, M.; Blakers, A.; Kaizuka, I.; et al. Solar photovoltaics is ready to power a sustainable future. Joule 2021, 5, 1041-1056. [CrossRef]

56. PROMOtion. WP 4.7 Deliverable: Preparation of Cost-Benefit Analysis from a Protection Point of View; PROMOtion Project 2020. Available online: https:/ / www.promotion-offshore.net/ (accessed on 2 December 2021).

57. Koivisto, M.; Maule, P.; Cutululis, N.; Sørensen, P. Effects of Wind Power Technology Development on Large-scale VRE Generation Variability. In Proceedings of the 2019 IEEE Milan PowerTech, Milan, Italy, 23-27 June 2019.

58. IRENA. Renewable Power Generation Costs in 2018; IRENA: Abu Dhabi, United Arab Emirates, 2019.

59. Department for Business, Energy and Industrial Strategy. Electricity Generation Costs 2020; Department for Business, Energy and Industrial Strategy: London, UK, 2020.

60. Hevia-Koch, P.; Jacobsen, H. Comparing offshore and onshore wind development considering acceptance costs. Energy Policy 2019, 125, 9-19. [CrossRef]

61. Langer, K.; Decker, T.; Roosen, J.; Menrad, K. A qualitative analysis to understand the acceptance of wind energy in Bavaria. Renew. Sustain. Energy Rev. 2016, 64, 248-259. [CrossRef]

62. Jansen, M.; Staffell, I.; Kitzing, L.; Quoilin, S.; Wiggelinkhuizen, E.; Bulder, B.; Riepin, I.; Müsgens, F. Offshore wind competitiveness in mature markets without subsidy. Nat. Energy 2020, 5, 614-622. [CrossRef] 